https://helda.helsinki.fi

\title{
In the shadows of social licence to operate : Untold investment grievances in Latin America
}

\section{Ehrström-Fuentes, Maria}

2017

Ehrström-Fuentes , M \& Kröger , A M 2017 , ' In the shadows of social licence to operate : Untold investment grievances in Latin America ' , Journal of Cleaner Production , vol. 141 , pp. 346-358 . https://doi.org/10.1016/j.jclepro.2016.09.112

http://hdl.handle.net/10138/178829

https://doi.org/10.1016/j.jclepro.2016.09.112

acceptedVersion

Downloaded from Helda, University of Helsinki institutional repository.

This is an electronic reprint of the original article.

This reprint may differ from the original in pagination and typographic detail.

Please cite the original version. 


\section{In the shadows of social license to operate: Untold investment grievances in Latin America}

- Maria Ehrnström-Fuentes ${ }^{\mathrm{a},}$,

- Markus Kröger

- a Supply Chain M anagement and Social Responsibility, Hanken School of Economics, Helsinki, Finland

- ${ }^{b}$ Department of Political and Economic Studies, University of Helsinki, Finland

- Journal of Cleaner Production, Volume 141, 10 January 2017, Pages 346-358, http://dx.doi.org/10.1016/j.jclepro.2016.09.112

This is a pre-print version of the article. For the final version, please go to:

http:// www.sciencedirect.com/ science/article/ pii/S0959652616314536

Abstract

This article critically examines the usability of the concept of 'social licence to operate' (SLO) in the Latin American context as an indicator of the social acceptability granted by local stakeholders to multinational forestry companies. We identify four potential problems (risks of co-optation, structural power imbalances, conflicting worldviews, and the silencing effects of global certification schemes) that emerge when the current practice and literature on SLO is implemented in the context of forestry operations in Global South's rural areas, commonly marked by dynamic and contentious corporate-community relations. Based on empirical material from local communities affected by industrial tree plantations (ITPs) in a setting claimed to have an absence of conflicts (U ruguay) and another where visible conflicts have been present (Chile), we then ask: What does SLO mean to those it is supposed to represent the most, the local communities affected by industrial forestry? The findings illustrate that caution is necessary prior to claiming that a company, investment, or industry has achieved an all-encompassing SLO at the local level. Instead, to understand the dynamic and contentious corporate-community relations we argue for a more nuanced approach to how locals engage with different economic alternatives based on their own placebased capacity to sustain and reproduce life in community.

Keywords

- Corporate-community relations;

- Conflicting worldviews;

- Extractive industries;

- Forestry;

- Latin America;

- Legitimacy;

- M arginalised voices 


\section{Introduction}

In the past decades, the forestry industry has undergone an intense period of internationalisation. This has signified that a large portion of the industry's raw material production has been removed from the critical eye of the conscious consumers in the Global North to geographically isolated and marginalised communities in the Global South (Kröger, 2010 and Kröger, 2013c). This in turn means that the forestry industry now shares many of the common features with extractive industries, in terms of how they are expected to engage (or not expected to engage) with local communities on the ground.

Intense conflicts have emerged with communities affected by the industry's investments both in places where tree plantations (Barton et al., 2012, Carruthers and Rodriquez, 2009, Gómez-Barris, 2012, Haughney, 2012, Kowalczyk, 2013, Kröger, 2012a, Kröger, 2012b, Kröger, 2013a, Kröger, 2013b, Kröger and Nylund, 2011 and Nylund and Kröger, 2012) and large-scale pulp mills have been located (Ehrnström-Fuentes, 2015, Ehrnström-Fuentes, 2016, Fougère and Solitander, 2009, Groglopo, $\underline{2012}$ and Kröger, 2007) (the term 'pulp investment' referring to both the tree plantations and the mill, plus infrastructure and other parts). In this conflict-ridden environment, embedded in a context marked by a plurality of ontologies, worldviews and moral convictions (Ehrnström-Fuentes, 2016), forestry corporations have embraced the concept of Social License to Operate (SLO) as a new concept that may ease their troubles, or at least guide their actions in the communities that they depend on for their operations. For example, Stora Enso (2015: 26) refers to SLO as a 'genuine effort' to make things better for local communities, and UPM (2015) describes SLO as 'a key element in sustainable forestry'. Thus, SLO is rapidly becoming a core concept in how global forestry corporations frame their community engagement (see also The Danish Institute for Human Rights, 2015: 16).

Due to its specific needs in terms of access to a significant amount of land for trees, which also affects how the locals engage with the surrounding environment, it has been argued that the forestry industry 'needs broad community support if the industry is to proceed and prosper' (Adams, 2011: 3). In this setting, SLO is seen as the social contract emerging from formal and informal institutional and social arrangements between land owners, forestry companies, contractors, resource-dependent communities and others (Edwards and Lacey, 2014 and Wang, 2005).

However, does the spread of this concept among forestry practitioners imply that the companies that claim to have a SLO have in fact achieved acceptance among those affected? We see SLO as a market-based concept where local grievances are downplayed, and where the most influential stakeholders (in terms of the financial bottom-line) grant the corporation its licence to continue operations. The concept follows the idea that stakeholders can be categorised as influential based on their 'salience'(M itchell et al., 1997), or their perceived power, urgency and legitimacy from the firm perspective (Wilburn and Wilburn, 2011). Thus, SLO goes as far as the corporation's interests and its own moral viewpoints are involved, but not necessarily beyond this point, leaving silenced grievances and different viewpoints on moral values in the shadows.

The trustworthiness of many global corporations is currently at a low point (Scherer and Palazzo, $\underline{2007}$ and Palazzo and Scherer, 2006) and such problems will not be resolved with the introduction of a new yet merely discursive twist, which amounts to little more than an empty promise. Thus, without examining SLO from the perspective of the locals, there is a risk that it only serves to momentarily extend corporate power over marginalised communities, while fuelling social unrest and aggravating tensions on the ground.

In this article, using empirical material gathered by field research on large-scale pulp investments in a setting claimed to be conflict-free (Uruguay) and another with conflicts (Chile), we ask: what does SLO mean to those it is supposed to represent the most, the local communities affected by industrial forestry? Our empirical examples of forestry conflicts in Latin America illustrate how this concept, which originated in 
the mining industry of the Global North, is to be re-considered when applied to the very conflicted setting of rural Latin America and the Global South. The current use of SLO does not account for the conflictoriented character of local forestry communities in ITP-based investments (see Gerber, 2011 and Kröger Kröger, 2011, Kröger, 2012a, Kröger, 2012b, Kröger, 2013a, Kröger, 2014 and Westoby and Lyons, 2016). ${ }^{1}$ To focus only on SLO may give the false impression that a given population would have unanimously accepted something, while neglecting the dynamic and contentious quality of firm-specific social acceptability in different contextual settings.

Based on our empirical findings, we argue that SLO is mostly an indicator of whether a certain activity has state support, since only the state can remove permits and officially reject investments. In this setting, both media and global certification schemes (Forestry Stewardship Council, FSC) play an important role impeding the broader public to become aware of local grievances and to pressure governments at the national level and key stakeholders at the global level to withdraw their support from these types of investments. To understand the dynamic and contentious relations at the local level of contested territories, we argue for a more nuanced approach to understand how locals engage with different economic alternatives based on their own place-based capacity to sustain and reproduce life in community.

We start by describing and outlining the background and existing literature on SLO. The second section identifies four problem areas in the current practice and literature on SLO in the Global South: 1) risk of cooptation; 2) power imbalances; 3) the impossibility of shared values in situations of conflicting ontologies; and 4) the lack of attention paid to the voice of the locals in global certification processes, such as Forestry Stewardship Council (FSC). In the third section, we provide empirical evidence, listing first the methods we used in our field research, and analysing the results. Finally, we use our empirical material from Latin American investment areas to deepen the analysis of practical problems and generate solutions to how local acceptability of different types of ways of living, including not only large scale investment coming from the outside but also alternatives visions on how to sustain and reproduce life in community that emerge or already exist within the communities themselves.

\section{Theoretical framework}

\subsection{The origins and meanings of 'social licence to operate'}

The term 'social licence' emerged in the mid-1990s within the mining sector as a response to social risk (Boutilier and Thomson, 2012). At this time, growing local opposition to resource extraction projects forced corporations to change their approach towards community stakeholders in order to guarantee smooth operations and access to local resources (Bice and M offat, 2014, Hilson, 2012, Owen and Kemp,

2012, Parsons et al., 2014, Prno, 2013 and Sing, 2015). In contrast to a statutory licence, which is granted by formal political or legal authorities to a firm to initiate operations, SLO is not defined by laws and formal procedures but guided by the idea that the community can hold the company accountable for its actions (Parsons et al., 2014). In this sense, SLO has been characterised as representing a set of demands and expectations held by a local community and civil society on how a business should operate locally in order to achieve social acceptability (Bice and M offat, 2014, Edwards and Lacey, 2014, Gunningham et al., 2004, Hall et al., 2012, M elé and Armengou, 2015, Parsons et al., 2014 and Prno and Slocombe, 2012). Some have even suggested that a more suitable concept would be a community licence, since the SLO is primarily related to the engagement with and acceptance from local community members, where wider societal views are considered of secondary importance in terms of their capacity to affect the mining operations (Parsons et al., 2014). In a recent study in the cross-industrial usage of the SLO concept, Hall et al (2012) found that business representatives considered the concept to have a stronger focus on the relational interactions with stakeholders near local operations than the already well-established Corporate Social Responsibility (CSR) and sustainability concepts: 
"In practice, SLO offers to extend stakeholder theory and the literature and practice of corporate social responsibility by providing a shared goal for both industry and community/ citizen stakeholders in negotiating development proposals. The target audience was consistently identified as being mainly focused on local community members in the site of development impact." (Hall et al., 2012, p. 307-308)

However, this literature that focuses on the local scale does not discuss the key notion that a claim of 'having achieved a SLO' by business practitioners is highly dependent on the visibility of the grievances in media (Ehrnström-Fuentes, 2015) and the support given at the national level (Zhang et al., 2015). Parsons and $M$ offat (2014) argue that often the expectations, perceptions and experiences of corporate behaviour are non-aligned, meaning that the SLO is also a way to try to build a positive corporate reputation for smooth future operations among key business stakeholders, not only locally but also elsewhere. This is particularly the case of certification schemes directed towards the end customers, such as the Forestry Stewardship Council (FSC). Within FSC, the mechanisms to deal with local grievances are the public hearings arranged for the locals affected by industry operations during the certification processes (Roberge et al., 2011), while the principal stakeholders of the certificate are the end customers of the paper products.

The potential disconnection between local realities and the interests of powerful stakeholders elsewhere exposes the SLO concept to one of its major weaknesses: how does it fit with the increasingly visible local resistance and separatist movements against extractive operations across the world (Banerjee, 2011)? M ore precisely, how does the spread of SLO as an indicator of local acceptance fit 'the voices of the governed' of translocal resistance movements? These are the "local communities living (and dying) in socalled democratic societies but governed in very non-democratic ways that are engaged in conflicts with both the state and the market, and sometimes even with 'civil society' while also making connections with other resistance movements in different parts of the world" (Banerjee, 2011:331).

Critiques of SLO have previously pointed out that the concept, in the way it is currently being used, may be used as a way of disguising or silencing opposition at the local level (Owen and Kemp, 2012, Parsons and M offat, 2014, Sing, 2015 and Westoby and Lyons, 2016). Kirsch (2007 in Sing, 2015) argues that in some cases the development initiatives set up by corporations undermine genuinely sustainable development by de-establishing social relations between opponents and proponents in the local community. In line with this argument, Sing (2015) describes the disruptions of the social fabric in a community next to a mine in Papua New Guinea, where the company offered compensation to only a fraction of the local community (a select group of landowners). He notes that while the compensation packages were successful in granting the mining companies a short-term SLO by mitigating local discontent among community landowners, these same activities also created vicious cycles of other negative impacts on the community. Hence, not examining the consequences of certain investments from a broad and longterm perspective undermines the credibility of the SLO concept itself while blurring the view of what constitutes responsible and sound investment policies.

\subsection{Limits to SLO as a win-win concept in the context of the Global South}

The proponents of SLO claim to align business and community values under a shared vision of how to run operations so that these can contribute to both maximum shareholder value while simultaneously providing the locals and the local community with measurable benefits in terms of compensation and community development programmes (Owen and Kemp, 2012 and Porter and Kramer, 2011). However, we identify several potential problems with this type of win-win approach towards corporate-community relations, particularly in the context of the forestry industry in the Latin American context.

\subsubsection{Taking seriously the claims of co-optation}


M uch of the literature on SLO focus on how the companies can and should contribute to the well-being of the community through social development programs and thereby create a favourable and conflict-free environment for their local operations (Bice and M offat, 2014, Harvey and Bice, 2014 and M artinez and Franks, 2014). However, this way of legitimising unpopular extractive investments, although it recognises the dangers of relying on 'cost-benefit' approaches to community relations (Harvey and Bice, 2014), often fails to address the broader societal circumstances that leave locals exposed to the ongoing need for external aid. The resource extraction policies of the past decades have left many peripheral communities vulnerable and in need of social investments in Latin America (Groglopo, 2012 and Silva, 2009), and elsewhere. Studying natural resource extraction in Africa, Collier (2010) has argued that the resource curse of countries dependent on commodity exports is more than economic; it is a political issue where politics affect the exploitation of natural assets, and natural assets affect politics. State funds have been directed towards corporate extractive investments, while the impacted local communities have been left mostly on their own - the large number of landless rural workers in Brazil, also in forestry investment areas, is a good indication for this tendency (Kröger, 2013a). While new corporate-led solutions may address some of the urgent needs of abandoned rural areas, this privatization of social policies may also serve to convince locals to accept the presence of less desirable operations in their community (Esteves and Vanclay,

2009, Groglopo, 2012 and Westoby and Lyons, 2016). Recent research on SLO in Chile indicated that mining corporations use community development projects as a strategy to enhance their social legitimacy in local communities affected by their operations ( $M$ artinez and Franks, 2014). The locals on the other hand were reported to have a mixed sense of fear, resignation and convenience towards the presence of the companies, and saw the development projects as a way of minimizing the risk of opposition towards the mining companies in their community ( $\mathrm{M}$ artinez and Franks, 2014). Thus, it may be very difficult to determine the extent of local support, or how locals make sense of SLO (even for the locals themselves) when the social projects that are set up under the label of 'social responsibility' or 'community development' promote much-needed investments in health and education, while the adverse effects that the core operations have on the local population are ignored or downplayed when publically debated (Groglopo, 2012 and Westoby and Lyons, 2016). This shift towards 'private politics' (see Soule, 2009) places the concept of SLO in a central position in understanding contemporary politics in the neoliberal era. In addition to the loss of public services, this shift also includes a privatized regulating model, where local regulation increasingly relies on external NGO consultants (partially privately funded), whose role is to within certain limits - assess private investments and engage citizens in decision making processes that affect their lives (see the example of FSC below). ${ }^{2}$

\subsubsection{Addressing structural power imbalances}

Experience in both mining and forestry in the Latin American context show that governments tend to side with corporate interests when these clash with those of local communities or civil society more broadly (Barton et al., 2012, Carruthers and Rodriquez, 2009, Gómez-Barris, 2012, Kröger, 2010, Kowalczyk, $\underline{2013}$ and Silva, 2009). The reason for the inclination of governments in the Global South to support corporate investment instead of proposals emerging from the communities themselves is a consequence of the structures of the modern nation states and the globalisation of markets. Since the mid-2000s, Latin American states have come to rely on a political economy of neo-extractivism (including but not limited to mining and forestry) balancing trade accounts and creating new social welfare policies while causing severe environmental damages and local conflicts (Acosta, 2013 and Gudynas, 2012). In extractivism, there is a shared interest between national governments and multinational corporations to maximise export and GDP growth. By giving their support to these sort of industries, governments can free themselves from global financial markets and debt by increasing exports of natural resources, contributing both to government revenues and stimulating employment (on the double role of the government see Zhang et al., 2015). Simultaneously, the unprecedented economic rise of China as the production hub of the world in the era of 
globalization has created a strong and growing global demand for natural resources. Within this context, Latin America has served as an important source of natural resource extraction (Gallagher and Porzecanski, 2010 and Kröger, 2012b). This creates imbalances between global economic interests and concerns at the local level. Thus, although the local support for an extractive activity may be weak, the state support towards these types of investments is not easily challenged. This surely affects how businesses uphold an image of having secured SLO also at the local level, as the government attitudes can be assumed to be positively biased towards the interests of the corporation and negatively biased against the concerns of the locals, leaving them vulnerable and marginalised in investment decisions that directly affect their lives.

Furthermore, how local voices are represented in the media (Ehrnström-Fuentes, 2015 and Pakkasvirta, 2010) may fail to capture the underlying mistrust of the community towards the company operating on their land (Owen and Kemp, 2012). Previous studies have shown how national and international media outlets that have failed to capture the critical voices towards forestry in Uruguay (Groglopo, $\underline{2012}$ and Kröger, 2007) and the sense of frustration felt by locals as a powerful actor enters their sphere of life (Groglopo, 2012) is a key example. This blurs the vision of the public of the real environmental and social consequences on the ground and also affects their attitudes towards the industry. What this discrepancy between a misinformed public and the sentiments shown at the local level means for the SLO has been overlooked in previous studies and the general public acceptance (Boutilier, 2014; M offat and Zhang, 2014; Zhang et al., 2015). However, as Owen and Kemp (2012) and Kröger, 2013a and Kröger, $2013 \mathrm{~b}$ note, the absence of visible conflict does not automatically guarantee that a corporate investment is accepted by the locals. Rather it may signify, for example, that community groups are in the process of regrouping their collective activities to voice their opposition, are without the resources or abilities to protest, or are withholding their grievances due to the complexity of how certain cultures express or do not express their sentiments in the form of organised actions such as public protests and demonstrations. (Groglopo, 2012). In addition, the structural effects of ITPs offer an additional ethical dilemma to the SLO concept: when tree plantations replace and remove communities from their lands (voluntarily through development induced-migration or by the force of eviction), there may be no "contested SLO issue because there is no manifest conflict" (Westoby and Lyons, 2016: 8). However, the adverse social impact of the forced migration, now relocated elsewhere (i.e. urban shanty towns), remains invisible and unattended within the realm of SLO, which primarily focuses in a predetermined set of social issues within the actual communities affected by operations.

\subsubsection{The impossibility of shared value creation in a setting of conflicting worldviews}

While stressing the importance of shared visions, values and understandings that foster the co-creation of common goals (Boutilier, 2014, Harvey and Bice, 2014 and Porter and Kramer, 2011), the reliance on SLO to describe local realities may unintentionally end up decimating a multitude of competing worldviews. In fact, the dominant rationality employed when decisions are being made in the context of the modern nation-state converges with that of the corporate world. These two follow the same ontological assumptions embedded in the modern worldview, such as, the belief in separation of man from nature, a linear perception of time tied to historical processes of industrialization, and hierarchical power relation between modern and colonial subjects (Blaser, 2010; Escobar, 2008 and Gudynas, 2011). In contrast, the worldview of local communities may be partly or entirely dependent on other knowledges, as is the case for Indigenous cosmologies that relate to nature and social forms of being through a different set of logic and feeling (Blaser, 2010; Escobar, 2008; Ruckstuhl et al., 2014). The communities' own visions of the future

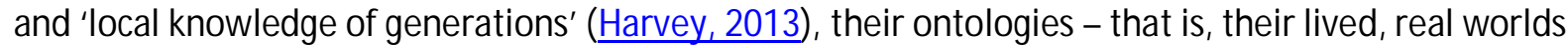
(Blaser, 2010) - do not necessarily desire the kind of 'development' or modernisation programmes (Escobar, 2011) that are promoted through the 'SLO jargon' of shared values and benefits (Ruckstuhl et al., 2014). In many Indigenous cosmologies of Latin America, 'natural resources' is a derogatory term in the 
ontology where Pachamama, or Nature, refers to the same thing but lacks the anthropocentric and modern burden (Escobar, 2008).

The local context may not be even closely homogenous in terms of values, norms and beliefs, which make it difficult to find common values to be shared among all locals. The multicultural Latin American contexts, with Indigenous and other landed populations with their own peasant-style human ecologies, often differ radically from European-descended landholders who establish agribusiness and other business-based investments aimed at profit maximisation in the same localities. This context of multiple ontologies and epistemologies makes it impossible to apply an ethical evaluation of SLO based on the kind of Eurocentric universalist principles of the common good and human rights that for example Melé and Armengou (2016) argue for in their take on how SLO can be secured. Such evaluation rather than contributing to solving conflicts, runs the risk of excluding the indigenous claims for the right to self-determinations while also occluding the values and views of those whose worldviews are not commensurable with the dominant modern ethical principles of what constitutes the common good (Ehrnström-Fuentes, 2016 and Hanna et al., 2014).

In addition, the use of the SLO concept also carries with it a view of local stakeholders as passive actors, whose agency or response to corporate hand-outs is always unified, linear and automatic, rather than spontaneous, uncontrollable and in the end solely in the hands of the locals themselves. The role, will and capabilities of potential resistance, which in the study of social mobilisations against forestry corporations has been called contentious agency by resistance groups (see Kröger, 2013a), is currently overlooked in the SLO literature. There may be situations where no SLO can be granted by (some or all) locals, under any circumstances. Acknowledging the diversity that exist within communities and still arguing that some sort of social acceptance can be achieved by changing engagement techniques (Dare et al., 2014) and including marginalised stakeholders (ذijelava and Vanclay, 2014) does not, however, solve the underlying problem: how to respect marginalised locals when their will is to remain outside the sphere of influence of any sort of license at all.

\subsubsection{Silencing locals through global certification processes}

In response to consumer boycotts against clear cutting old-growth forests and protection of natural habitat for endangered species (Joutsenvirta, 2011), as well as supply chain-operators' (e.g. retailers') demands for due diligence (Dauvergne and Lister, 2011), forestry companies have been pressured to rely on certification processes to guarantee responsible forestry management across the entire supply chain (or 'chain of custody' as referred to within the context of FSC). This practice where an external auditor certifies tree holdings based on standards set by different environmental NGOs, social groups, and industry representatives on global, national and regional levels (M oog et al., 2014,M ena and Palazzo, $\underline{2012}$ and Schepers, 2010) opens up new grounds on which the SLO must be secured through multi-scalar negotiations. The ten principles of FSC (SeeTable 1) aim to reassure the global stakeholders and endcustomers that the raw material comes 'from well managed forests that provide environmental, social and economic benefits' (ㅌㄷ, 2015).

Table 1.

FSC's ten principles for responsible forest management.

Principle Compliance with laws and FSC Principles - to comply with all laws, regulations, 1: $\quad$ treaties, conventions and agreements, together with all FSC Principles and Criteria. 
$\begin{array}{ll}\text { Principle } & \text { Tenure and use rights and responsibilities - to define, document and legally } \\ \text { 2: } & \text { establish long-term tenure and use rights. }\end{array}$

Principle Indigenous peoples' rights - to identify and uphold indigenous peoples' rights of 3: ownership and use of land and resources.

Principle Community relations and worker's rights - to maintain or enhance forest workers' 4: and local communities' social and economic well-being.

Principle Benefits from the forest - to maintain or enhance long term economic, social and 5: environmental benefits from the forest.

Principle Environmental impact - to maintain or restore the ecosystem, its biodiversity, 6: resources and landscapes.

Principle Management plan - to have a management plan, implemented, monitored and 7: documented.

Principle Monitoring and assessment - to demonstrate progress towards management 8: objectives.

Principle Maintenance of high conservation value forests - to maintain or enhance the 9: attributes which define such forests.

Principle Plantations - to plan and manage plantations in accordance with FSC Principles 10: and Criteria.

Source: FSC 2015.

Table options

However, the groups that are engaged in the standard setting work at the national level, and the key stakeholders towards whom the certifications are directed - primarily customers at the end of the supply chain (Schepers, 2011) - are not always well connected to concerns at the local level (Cashore, 2004, Johansson, 2014a, Johansson, 2014b and M cDermott, 2012). This lack of attention to differences between global and local stakeholders opens up gaps between those with power to influence on the design of the FSC and those without. Thus, the implementation of certifications risks drawing yet another veil over those local grievances that do not fit the globally agreed upon certification standards. Instead of securing the well-being of the local community, these global processes may end up silencing the local rejection of a business model that does not fit the locals' own view on community well-being.

In sum, the primary question that arises from the problems discussed above is how the concept of SLO accommodates to the needs and views of the locals themselves. Building SLO on exclusion and occlusion cannot be a sound investment policy. Instead, the long term consequences are completely contrary to what the proponents of the SLO concept aims to achieve: social conflicts such as protests, road blockades, consumer boycotts, media campaigns, legal charges and verdicts on environmental and livelihood destruction (Parsons et al., 2014 and Sing, 2015). These contentious politics can ultimately result in the withdrawal of legal permits on behalf of authorities or the voluntary closure of operations on behalf of the corporation (for unsuccessful SLO cases, seePrno, 2013). M assive, disruptive and pioneering protests such as tree plantation occupations have been found to be decisive in affecting forestry expansion trajectories around the world (Kröger, 2013a). Protests impact the perception of investments as conflictive or conflict- 
free (Gerber, 2011). In this sense, if one was to study the politics of SLO, to focus on protests would be an essential component, however, this study illustrates through the case of Uruguay and peaceful corporatecommunity stakeholder meetings in Chile how settings with few visible protests can in fact lead to a false idea that there would be an SLO. The absence of protesting is not a sufficient condition to claim that there is an SLO. Thus, we explore what - in situations of conflicting interests, values and ontologies - SLO mean to those it is supposed to represent the most, the local communities affected by industrial forestry? To answer this question, we next move to the empirical part of our analysis.

\section{Methods}

The empirical material consists of semi-structured in-depth interviews with local community members in areas affected by tree plantations and with experts in Uruguay and Chile. The use of empirical material from two different research settings allows us to identify similarities and differences in how community members make sense of forestry SLO. The Uruguayan and Chilean cases represented similarities in local conditions (both had local forestry conflicts), but differences in how SLO was publicly contested (Ehrnström-Fuentes, 2015 and Groglopo, 2012) - this type of research setting is useful for exploring the complex relations between having or not having a SLO in the local context.

The bulk of the empirical material represented in this article consists of formal and informal interviews conducted with local community members, primarily from people who are critical voices against the forestry sector in Uruguay and Chile. The reason for this selection is that the concept SLO is commonly used to establish an image that there are few or no critical voices of the operations. Focusing on outspoken critical accounts against forestry operations makes it possible to identify the discrepancies between proponents of the SLO concept and the voices of opponents. Addressing the power imbalances that we discussed above (media misrepresentation, how certain cultures deal with conflicts, ontological differences etc) means that methodologically we cannot rely on sentiments expressed in public discourses as a reliable indicator of how locals lend support to operations on their land. Such an abstract measure may be an outcome of the locals either being either afraid to speak up, or of systemic exclusion of certain voices in the public sphere (Ehrnström-Fuentes, 2015).

A large number of informal and short interviews (discussions) typical to field research with those community members without a clear stand for or against the conflict were also conducted in natural encounters with locals as a visitor in these places (i.e. taxi drivers, restaurant personnel, hotel personnel, shop owners, local journalist, individuals waiting a bus stops, etc.). The material also included the transcription of a three hour-long public hearing held in preparation for the FSC certification of ITPs in 2012 in the town of San José de la M ariquina in Chile. The collected material is backed up by a larger database of observations from global industrial forestry collected through extensive field research by one of the authors since 2004, which makes it possible to place the new data into a broader context.

In Chile, a total of four interviews were conducted with participants after the FSC certification process public hearing (duration 10-30 min each). An additional ten in-depth interviews were conducted with locals who had been involved in resisting the establishment of a pulp mill in their community (1-1.5 h each). These interviewees where identified and contacted using the snowball method, with help from local researchers knowledgeable of the conflicts. The interviews and the public hearing in Chile, all recorded and transcribed, took place between September and November 2012.

In Uruguay, the contacts with the interviewees were established through a Finnish journalist that had visited Uruguay during the Botnia/UPM pulp conflict and through the M ontevideo based NGO Guayubira, actively supporting Uruguayan farmers in their struggle against eucalyptus plantations on their land. This connection was essential to overcome the gatekeeper problem and gain access to the critical voices in the community. A local activist in the city of M ercedes connected to Guayubira helped identify locals who had, 
at some point, been engaged in resistance against ITPs. A total of eleven interviews (1-1.5 h long) were recorded and transcribed from the field visit to different communities in Uruguay in November 2012. The recorded interviewees included five farmers living or having lived in areas affected by or under the threat of being affected by ITPs; one honey bee keeper in a city surrounded by forestry plantations; two members of different environmental NGOs based in M ontevídeo; one alternative radio channel journalist in M ontevideo; one activist engaged in the opposition towards forestry based in Fray Bentos; one veterinarian based in the city of M ercedes; and one state prosecutor based in M ontevídeo.

The interview questions varied depending on the context and the interviewee. The preliminary interview questions were raised to find out about how the interviewees related to the forestry industry in general, and whether the interviewees considered the presence of forestry companies in his or her community as socially acceptable. In addition, questions regarding engagement in dialogues and seeking a common understanding with the corporations in order to find common solutions to their grievances were raised.

The material was analysed based on references made by the interviewees to any of the six topics presented above: grievances, conflict cultures, media, shared benefits, political ontologies, and certifications.

\section{Findings and analysis}

\subsection{Uruguay: State support}

Uruguay illustrates how a national industry that appears to hold a SLO might not, in fact, have secured a local support among its locally affected stakeholders. In Uruguay, the key issues of recent forestry investment, which has focused on pulp investments with eucalyptus ITPs, have been related to concerns about water pollution by the pulp mills and their effect on the local economy, whereas the effects of ITPS on the surrounding community have not received as much attention (Kröger, 2007 and Groglopo, 2012). Company representatives and political leaders have justified the growing presence of the industry by referring to the benefits accrued from mill investments, and appear to have little concern for the consequences of ITPs in local communities: they downplay the concern of the availability of raw materials and the impacts of its extraction (Groglopo, 2012). Rural dwellers affected by ITPs have been side-lined, while the political leadership, including the progressive but extractivist-strategy favouring President J osé M ujica (Gudynas, 2012), has turned from an initially critical stance towards global forestry operations as a threat to an alliance with the industry. The president argues that Uruguay has few alternatives to the current national forestry model:

'[The pulp mills] have indirectly employed more than 10,000 people working for them permanently with better salaries than what we had before and they also bring currency income. We are a small country that needs to import a lot, but this industry is now exporting pulp for the same amount as the meat industry, this year for approximately two billion dollars. This means that for us, under our circumstances, this is beneficial.' (J osé M ujica in YLE interview, September 2014)

This political stand that paints the arrival of the forestry industry as both beneficial and inevitable, while obstructing the criticisms raised about land use policy and the risks related to the long-term consequences of what Piñeiro (2012) denominates the 'foreignisation' of land-ownership. Out of Uruguay's 16.4 million hectares of agricultural land, approximately one million are covered with pine and eucalyptus plantations, mostly in the hands of foreign owners, the largest being the Finnish-Swedish company, Stora Enso, and the Chilean company, Arauco, with a joint ownership of 234,000 ha, followed by the Finnish company, UPM Kymmene, with 200,000 ha (Piñeiro, 2012). The rapid growth in tree plantations on agricultural land stems from the Forestry Law of 1987, which promoted industrial tree plantations by establishing tax-benefits and subsidies for planted forests. Although these benefits have since been revoked, the private investment in forestry continues to grow. Piñeiro (2012) analysis of the long-term effects of foreign land purchases and 
leases in Uruguay points at the draw-backs of this model (e.g. disappearance of farms dedicated to food production and changes in what kind of crops can be produced profitably). The critical voices raised in the conducted interviews of Piñeiro's study indicate that it is a model that promotes large-scale, exclusivist, corporate, and foreign interests, while provoking a profound effect on the country's agrarian structure and in the long-term also changes in who holds the actual power in the national political system. Temporal considerations: the changing SLOS.

As indicated above, farmers in Uruguay have experienced drastic changes in land use since implementation of the Forestry Law in 1987. This makes it possible to conduct a longitudinal analysis of how time influences SLO dynamics. The accounts of affected farmers that were interviewed suggest that prior land uses had a better local support than the new land use focused on forestry development. One farmer explained the conundrum in these terms:

'I've been here for 38 years, and when I arrived I had many neighbours. From here, one could see five or six neighbours. Today you do not see anyone and this landscape repeats itself for $15 \mathrm{~km}$. Over there, there are 20,000 ha of eucalyptus; there are no people left, no people left. ... It does not make sense. Besides, they made a law, the forestry law, for the needs of these companies, but they do not even fulfil that because one of the clauses of the forestry law says that the land that does not serve for anything else is to be declared forestry priority. But here clearly the land did serve for other things; all of us, who lived here before there was eucalyptus, had other things that were better than eucalyptus.' (Smallholder Soriano, November 2012).

The reference made to the migration of people above, also shows how the power of the locals to mobilize and protest diminishes when the plantations take over the landscapes once inhabited by a vibrant community.

A state prosecutor noted that in comparison with the negative image of mining operations held by the public in Uruguay, the prejudice against forestry operations is something that grew with time as the real consequences became evident. He compared forestry to mining, arguing that the change provoked in nature by mining is visually more shocking and immediate, while the negative effects of forestry and the fact that the plantations did not fulfil the originally promised benefits could only be noted several years after the trees had been planted, which was too late to stop the installations (State prosecutor, Montevideo, November 2012). Another interviewee noted that in the beginning, it was promised that the tree plantations would generate development and jobs in the countryside, thereby revitalising rural communities that had been hit by several agricultural crises in the past:

'The local producers did not disapprove of forestry at first. They though it would give them more work. But when they started to notice that the plagues of wild pigs and viper snakes increased and that the water started to disappear, they realized that this was not as good for them as they had been told.' (NGO representative, M ontevideo, November 2012)

These observations indicate that local acceptability can change over time, as previously unaccounted grievances become increasingly severe for affected groups. In this case, the already established and strong state support becomes particularly problematic considering the often long-term and compounding grievances and problems that large-scale investments can have on local populations. This change of attitudes over time also raises questions about the role of Environment Impact Assessments (EIA) and other mechanisms (i.e. the ILO Convention 169 on Free Prior Informed Consent of Local (Indigenous) populations) that aim at engaging local actors in the participative processes prior to the investment decisions ${ }^{3}$ (Bice and M offat, 2014, Costanza, 2015 and Hanna and Vanclay, 2013). These regulative systems may not serve their purpose to mitigate local grievances or produce informed consent, if the wider consequences of a particular investment are not known to the locals or the general public prior to its installation. 


\subsubsection{Dismantled opposition after changes in government}

The sudden change in position of the leftist Frente Amplio party, from having been against the forestry model to openly supporting forestry investments, after they won historical elections and took over the government from right wing parties in 2005 was, according to all the individuals interviewed, an important contributing factor that ended public mobilization against forestry. However, as the excerpts above show, and previous research corroborates (Owen and Kemp, 2012, Kröger, 2013a and Kröger, 2013b), an absence of visible protest does not automatically suggest that the industry or a specific investment project would have a local support. Those critical of ITPs and pulp mills supported (and were themselves supported by) the Frente Amplio coalition before elections, creating an expectation of change in policy among those opposing the forestry model. One interviewed farmer who was part of this effort and the tumultuous changes in political attitudes commented on the discrepancy between how the government and the community perceived the SLO of the forestry industry in the following manner:

'I think really this has become political [referring to the effect that ITPs have on the rural population], we had meetings with Mujica here in the farms and he was against the forest plantations. Now he is in government and he forgot everything about our farms and this is affecting the whole area, the schools, everything, now everything is planted ... When M ujica became president he sent ministers to our meetings that tried to convince us that planting is good. There is no help from the government.' (Former smallholder, Mercedes, Soriano, November 2012)

The changes in the political support for those opposing plantations and pulp mill investments shows how electoral politics can over time dismantle opposition towards projects and thereby impact the SLO. The Uruguayan case illustrates that the state support does not necessarily depend on the governing political party, since support for the industry remained stable despite the change in government to a party that was initially openly critical towards these types of investments. Instead, the local opposition might be affected and dismantled when the party changes its position after winning governmental elections.

\subsubsection{Media biases favouring SLO}

Following the change in governmental attitude, media coverage of the negative aspects of forestry for the local communities decreased. All the local informants expressed their frustration over how national media outlets (the television and the most important newspapers) ignored the realities lived next to ITPS.

'The people do not find out about the problems and the press does not allow for this information to spread. The television, in the home of both the poor and the rich, is on all day and I can tell you that the information against mining and against forestry does not exist there. On the contrary, they make us appear as anti-patriotic, because those who talk against these big investments are anti-national. That is the information that they give to the people.' (Veterinarian, Mercedes, November 2012)

This excerpt highlights that once a strong state support is created, it becomes hard to verify whether there is a true local support, as the state position can be used to discredit all critiques as mere outsider (foreign or other) voices that cannot be accounted for when measuring the extent of SLO. It also illustrates how media records are not a reliable indicator of local support when media interest closely follows changes in official government policies. Instead, the suppression of critical voices in the media can increase affected peoples' grievances and increase the likelihood of serious, compounding conflicts.

Around the same period that the changes in government destabilised the previous resistance against tree plantations, the effects of Argentinean protests against the pulp mill in Uruguay further marginalised the critical voices in Uruguayan media outlets. The construction of the Botnia pulp mill became an international dispute for national honour between Uruguay and Argentina. This made a serious discussion of local 
impacts extremely difficult as the level of political debate resembled a war, and those with a critical voice were framed as dissidents (Groglopo, 2012, Pakkasvirta, 2010 and Kröger, 2007). One interviewee compared the way the Botnia (now UPM) dispute between Uruguay and Argentina was handled in the national press to a football game: 'it was a football match that we had to win against Argentina, so now we have to celebrate because the mill is ours. A lot of people take it as a triumph, and then it is fine that they continue planting trees that feed these mills.' (Alternative radio journalist, M ontevideo, November 2012).

Our interviews from Montevideo show how the ignorance of community grievances by the majority of the population also impacts the perception that there is an SLO in a setting of locally marginalised discontent:

'The majority of the people have not done the job of becoming informed and they do not have a clue about what happens with the monocultures of trees in the interior of the country, the scarcity of water and so on. I would say that seven out of 10 people do not know and do not care. And I think that they believe in this discourse that comes from the industry about development and the generation of employment, and afterwards when the industry ends up having only 300 employees it is not such a big deal to them.' (Alternative radio journalist, M ontevideo, November 2012)

This claim is supported by previous research. For example, Piñeiro (2012) argues that rural problems are a distant concern for most of the Uruguayans, as only 9 per cent of the total population lives in the countryside. This finding raises yet another general concern about the conceptualization and measurement of SLO: what about the people who do not care? Do abstaining votes count or not? What if only a tenth of the locals have any opinion at all on a project and the rest do not have any opinion - would it not be more apt to claim that in such cases there is neither clear social acceptability nor rejection, than a secured SLO? This highlights the difficulty of addressing SLO without considering the degree of public awareness and the formation of public opinion, both nationally and locally. Future research should identify such situations and engage in understanding the complex relations between public (un)awareness and social acceptability.

\subsubsection{Conflict culture as preventing the visibility of conflicts}

The dominant conflict culture in Uruguay was described by several of the interviewees as one that places much trust in authorities and where people tend to conform to rules rather than engage in conflicts (Activist, Fray Bentos, November 2012; NGO representative; November 2012; Smallholder, Tarariras, November 2012; Alternative radio journalist, November 2012). This conflict culture influenced how many locals positioned themselves and accepted the presence of forestry operations in their community. The projects were believed to be beneficial because, as one interviewee put it: 'the government is bringing this here, so it must be good' (Activist, Fray Bentos, November 2012). Although people who initially spoke well of the company started to change their minds, the conflict culture prevented easy emergence of open contestation: 'but since no one is ready to stick their head out when it comes to these issues, the people here only say these things quietly, being scared' (Activist, Fray Bentos, November 2012). These sentiments expressed are supported by previous research on the Botnia (now UPM) pulp mill conflict in Fray Bentos (Groglopo, 2012: 180).

These findings show how difficult it can be to determine the acceptability of investment projects when cultural aspects limit community members from publicly raising their concerns and taking a stand against projects that have state support. Because of this, local support cannot be solely determined on the absence of visible, open conflicts. Instead, the degree of community acceptability is embedded in a context that can be impossible to grasp for an outsider without knowledge of the local culture.

\subsubsection{SLO from FSC certification processes}


All plantations in Uruguay are FSC certified. However, our data indicate that the social and economic wellbeing of the community (FSC Principle 4) does not necessarily include the views of all local key stakeholders, particularly not those who live adjacent to the plantations, and whose voices were marginalised during the certification process of the FSC. One farmer felt that the FSC certification serves to legally justify the plantations while hiding the damage experienced by the farms (Smallholder, Soriano, November 2012). Another farmer noted that their concerns were not taken seriously during the local meetings organised by the FSC auditors:

'We participated in several meetings but we were the rural and they the technical. They made us graphs, we arrived to make our point because they wanted to change our mentality saying that forestation was profitable, that there was no prejudice in that - but we had already started to experience the problems. I mean, what they mentioned there was a big lie, they fooled the people with propaganda and money, because the press came to see the people - but with lies.' (Former smallholder, M ercedes, November 2012).

None of the interviewees in Uruguay felt that the FSC certification offered them the opportunity to make their voices heard, or the opportunity to have any impact on how forestry was practiced in Uruguay. This problem is also typical and endemic to FSC in Brazilian tree plantations, as documented by Kröger, 2010, Kröger, 2012a, Kröger, 2012b, Kröger, 2013a and Kröger, 2014 and M yllylä and Takala (2011). The methods used to collect information on the impacts of the plantations on the local community were also questioned, as one of the interviewees put it:

'In terms of the certificates and the control here in our country, it is a disgrace. The question is how do they do the certifications, what methods do they use, which areas do they investigate? Here we have no guarantees that things are done well or with honesty.' (Activist, Fray Bentos, November 2012)

\subsubsection{SLO: the outcome of a favourable local context}

Based on interviews with sustainability and sourcing managers located further down the industry's supply chain, in contrast to Brazil or Indonesia, Uruguay is considered to be a source of responsibly and sustainably produced raw materials in a conflict-free setting (Ehrnström-Fuentes, 2012). The absence of Indigenous populations in Uruguay and a low rural population density are key arguments and simple facts that companies can convincingly use to assure any potential query regarding their SLO in Uruguay. As a consequence, external stakeholders (including international media) who do not have direct contact with the realities of the affected farmers or other critical opponents lack the basic understanding upon which the Uruguayan SLO could be questioned. We next move to the case of Chile.

\subsection{Chile: Absence of local support}

In contrast to Uruguay, Chile has experienced a SLO watershed event that marked a 'before and after' (Sepúlveda and Villarroel, 2012) for how forestry companies engage with the public, and legitimise their presence in local communities (Delamaza, 2012). Since the environmental damage in 2005 in San José de la $M$ ariquina, where a natural reserve for breeding black-necked swans was destroyed by effluent from a recently initiated pulp mill, the forestry industry has increasingly invested in good neighbour programmes in the communities where these companies operate (Delamaza, 2012; Interview with industry representative, Santiago, December 2012). In contrast to the Uruguayan foreign owned multinationals, Chilean forestry companies are owned by the Chilean elite and are constantly being monitored by human rights groups (Human Rights Watch, 2004). This is due to land conflicts with the M apuche Indigenous groups (Carruthers and Rodriquez, 2009; Gómez-Barris, 2012; Haughney, 2012 and Kowalczyk, 2013), where tree plantation expansion is a form of violent land grabbing, enclosure and dispossession through 
ITPS - activities that have been largely side-lined in the discussion of SLO in the forestry sector (Kröger, 2013a).

In spite of the above problems, forestry does have a strong state support in Chile. The forestry sector is of national importance because of its role as a key industry for export income and industrial growth, and vast subsidies have been given for ITPs since the 1970s (Clapp, 1995). The Mapuche claims to regain control and autonomy of their ancestral land, now used for ITPs, have not been recognised under Chilean law and those engaged in reclaiming their ancestral rights have been charged and convicted under a modified version of the anti-terrorism law that was put in place by the military government of Augusto Pinochet ( $\underline{\text { Kröger, }}$ 2013a, Carruthers and Rodriguez, 2009 and Human Rights Watch, 2004). In recent years, several documentaries have exposed the public to the issues at stake from the perspective of the Mapuche and their cosmovision (Fernández and Henríquez, 2009 and Varela, 2011), which together with books published by Mapuche authors (Cayuqueo, 2012, Comunidad de Historia Mapuche, 2012 and Marimán et al., 2006) has increased awareness outside the local, and often marginalised, community sphere.

\subsubsection{Problems in trying to achieve SLO through compensation and FSC}

A part of our empirical material in Chile was collected in connection with a three-hour-long FSC public hearing in the town of San José de la Mariquina in September 2012, when the Chilean forestry company Arauco was going through the certification process for its plantations next to the Valdivia pulp mill. During the meeting, several participants raised concerns about the effects of the plantations and logging in their community. They reported issues of water depletion, dust from the roads leading to the logging areas, 4 loss of biodiversity, plantations encroaching on sites of cultural significance to the Indigenous population, and the decreased quality of life as a result of the installation of tree plantations next to their homes.

One participant raised a concern about the effects that the company's social responsibility practices had on the local authorities and elected members of the local government:

'Today, how are we to understand this concept of social responsibility in the municipalities of this region? That the company is practically subsidizing the whole municipality? I am not surprised that local authorities modify the regulating plans over how land is used [from fit for agriculture to forestry use]. In this municipality, every year the company distributes corporate presents worth millions of pesos. It is distributed through the local city council, and it repeats itself in other city councils in this region. So there is also a responsibility of the current local city council members.'

The FSC auditors noted that as long as the corporate behaviour is within the limits of the law, it is not in conflict with the standards, and that in fact this kind of contribution to the local economy could be perceived as a form of 'social mitigation' for extracting resources, returning some benefits to the state and the local community. However, another local community member noted in a separate interview that the price of food in the community has been steadily rising while the availability of local produce is decreasing - which suggests that this type of contribution is not enough to mitigate the effects that the industry has had on the local economy. One participant suggested that the company should 'freeze in hell before it is granted the FSC certificate due to all the problems that existed in the region' because of how it had handled the environmental concerns that emerged when the pulp mill started its operations. The FSC auditors avoided this criticism saying that they did not look at the mill operations.

Some claims referring to the respect of Indigenous peoples' rights (FSCs Principle 3) were raised during the meeting (i.e. plantations located on ancestral sites and cemeteries). However, considering the contentious relation between some M apuche communities and forestry companies (Barton et al., 2012, Carruthers and Rodriquez, 2009, Gómez-Barris, 2012 and Kowalczyk, 2013), it is interesting to note the observation made by one $M$ apuche leader in a separate interview: 
'Even if no one turns up at the public hearings, they will still be certified. The companies buy their certifications. One company handed out bags of potatoes along the entire coastal line so that people could grow potatoes. They bought their certificate. The companies only need to engage with the communities to be certified. They do not listen to our proposals. They should not hand out bags of potatoes so that they can be certified ... if this does not change, we will continue to watch how they make money on our territories while we are dying of hunger. That is when we will want to take the forest from them and then the conflict never ends.'

This suggests that organised public hearings within FSC are not a guarantee that affected voices have been considered in the certification process. Consequently, one cannot claim that a forestry operation would have local support because it has successfully completed the FSC processes. Furthermore, the excerpt above raises questions of how philanthropic gestures that are employed before and during the certification processes impact the attitudes of locals (see also the previous reference made to corporate gifts at the municipality level).

Thus, the findings both from Chile and U ruguay indicate that the FSC certification process cannot guarantee that there is a local support for forestry operations. While the general perception further down the supply chain seems to be that the social concerns of locals are included in these practices (see Ehrnström-Fuentes, 2012), our findings show how certain claims raised by locals do not enter the standards set by the FSC. Inadvertently, in political terms, the FSC seems to be going in the opposite direction to what it was originally designed. Instead of ensuring externals that an investment stands on a firm ethical and sustainable ground, is free of conflicts, and locally accepted, in the cases we have observed, the certificate places the reality of a rejected SLO in the shadows, and then window-dresses the setting as having a complete SLO. Second, FSC strengthens the perceived SLO vis-à-vis local support: this is because companies and states can use the certificate as a shield against claims that there would not be any local support. The people who want to question the SLO have to overcome not only local political barriers, but also the international governance setting of the FSC to gain legitimacy for their claims.

\subsubsection{SLO in the context of open conflicts and unsettled territorial disputes}

In any corporate responsibility programme or certification scheme, including FSC, companies must comply with local laws before they go beyond them (FSC principle 1). However, in terms of securing SLO, what happens when the local laws have already been rejected by the local population due to their perceived injustice? Several community members did not believe in the Chilean laws or the authorities. In fact, they felt the laws were made to protect powerful interests and that only those who can afford lawyers were protected by the law:

'Against the laws emitted by the government, our community can do nothing. We are obliged to live with them and suffer from them. This is the reality that we are living. Some time ago, we tried to have a meeting with CONAF (the National Forest Agency in charge of the management of the country's forest resources) authorities, to ask them to look into the issue of companies planting areas meant for agriculture. But they (CONAF) do not have enough power to confront the company.'

The historical processes marked by conflict between the state and some Mapuche communities go so deep that it is not even possible to envisage a true SLO for Chilean forestry in M apuche territories. The lack of dialogue and deeply rooted mistrust towards the company, certifying agency and government, was a topic of great importance during the interviews we conducted. Among those who felt most discriminated against by the company and the Chilean government, there was little hope in achieving a common understanding with regard to how the company should relate to the locals: 
'There can't be any agreement with them, because there has been so much abuse, so much humiliation, so much pain that they have made us suffer these big multinational companies and the government ... It has cost us death and suffering. There are people still in prison, they are condemned for fifteen to twenty years - today, in a democracy, in the 21st century ... So the trust has gone. And to regain trust, I do not think it is that easy to regain it ...I cannot hit my wife, for example, and the next day pretend that I am happy, knowing clearly that inside, between me and my wife, there is tremendous pain.'

This excerpt highlights the need to include an analysis of power relations and politics centrally in future SLO studies.

\subsubsection{The ontological impossibility of shared benefits in indigenous territories}

The solution to the Mapuche conflict cannot be redeemed with money or shared benefits. The Indigenous culture is based on a fundamentally different relation to land and community than that of forestry firms. The basic difference is that in modernity and capitalism, nature is commoditised and monetised in an effort to make things commensurable in quantitative and monetary terms (Moore, 2014 and Kröger, 2015), whereas in many Indigenous cosmologies such a modernisation process fundamentally conflicts with communal ontologies. This conflict became evident in how accepting compensation for the loss of livelihood offered to the community members on behalf of the company was referred to as 'selling out':

'Look, they have even offered me 20 million pesos, imagine, my children, my grandchildren would be saying: my dad sold out for 20 million. And what about my health? I am from the hills, the last hill up there, that is my territory, my grains. Imagine, we used to make good sales from our produce before 'the eighteenth' [Chilean independence day], but now there is no water. There is no water. [...] but what is the point in telling them to leave, when in the end they will never talk to us - the Mapuche.'

This excerpt exemplifies how the Mapuche are not 'buying into' the conversion scales offered to them by the rationale of capitalism - where everything can be given a monetary value - but rather places the discussion onto a larger ethical and moral platform of the role of ontological differences in natural resource conflicts (see Blaser, 2010). Such discourses and stances can be used in SLO evaluation to determine whether there are ontological cleavages in a setting: their existence suggests several epistemological barriers for achieving SLO when the ontological differences cannot be overcome through mutual understandings (see Ehrnström-Fuentes, 2016). However, communities, even Indigenous ones prone to contention, have internal cleavages and are prone to change under pressure - what happens to SLO in such situations and how does the pursuit of SLO by corporations affect these community dynamics? One of the interviewees, who believed there could be improvements in community relations by engaging in a dialogue with the company, claimed that his engagement in conversations with the company provoked resentment among other community members accusing him of selling himself to the company:

'I know what it is to sell out and not to sell out, I am clear on that. And that is not the case when forestry is working with us, which I think is good. There are things that can be solved by us demanding better conditions from the company.'

This difference in belief systems and approach towards the forestry sector between community members highlights the fact that there are contrasting positions and claims, and different historical and contemporary differences in terms of how members of the Mapuche community see their own identity and ethnicity in relation to the dominant national culture (Kowalczyk, 2013), and that these differences contribute to a lack of common perspectives in traditional M apuche settlements (Barton et al., 2012). In terms of SLO, and as previously argued based on findings from the mining industry (Sing, 2015), these differences among locals may create ruptures in the social fabric and conflicts in terms of how community members relate to each other and the corporate project seeking its SLO in the community. 
The references made to 'selling oneself' raise questions regarding the ethics of compensation packages and community development initiatives offered by companies looking to secure a SLO. Such initiatives have recently been promoted as a solution to the current loss of corporate legitimacy among different stakeholders by creating a shared value that 'enhances the competitiveness of a company while simultaneously advancing the economic and social conditions in the communities which it operates' (Porter and Kramer, 2011). However, for those whose livelihoods, identities and entire belief systems are at stake, the push to create a SLO for large-scale extractive projects may be interpreted as an attempt to silencing opposition, co-opting fellow community members, and trying to create ruptures in local resistance to the project itself.

\section{Conclusions}

We have assessed the concept of SLO from the perspective of locals affected by the forestry industry in the Global South, more specifically in Uruguay and Chile. If having a SLO means that a host community can hold a company accountable for its actions, then our analysis does not suggest the forestry industry has been successful in its efforts in achieving such a licence. Based on our data, the discontent with industrial forestry is apparent among those whose living conditions are threatened by the companies' core business operations (i.e. the spread of tree plantations in and around their communities). The findings also suggest that if the industry enjoys a SLO at some level, it is not the locals that have been the main actors in granting them this licence; rather it is an outcome of more complex, global, national and upstream supply chain processes that hide the grievances experienced by those living next to tree plantations.

Although the SLO is framed as being a primarily local concept (Owen and Kemp, 2012, Parsons et al., 2014 and Prno and Slocombe, 2012), our findings indicate that most of the actual politics wherein the perception of having SLO revolves around how a company is perceived by global, state and other actors outside the local sphere. For example, according to several of the interviews conducted in Uruguay, media outlets function as gatekeepers of SLO by promoting industry interests as socially acceptable, while at the same time leaving the local grievances in the shadows.

Furthermore, the social acceptability of the firm may be questioned when locals notice real tangible effects of the operations on their own lives. It is very hard to claim that an investment could have SLO before the locals have had a chance to really understand the effects of the investment: any pre-investment SLOs are bound to change with time. The converging double trajectory of a slowly-unfolding community rejection of operations in forestry and a silencing of criticism by the state explain how forestry can uphold an image of a well secured SLO, while its status is being contested locally.

Even local community consent can be an unreliable indicator of SLO in the long term: meaning that SLO in its current form and understanding is not a good predictor for investors on the risk of an investment (the term is thus unreliable in this way). Our temporal analysis in Uruguay suggested that more conflict is on the way - attitudes can change as the impacts become visible. Yet, mobilization is not an automatic response to grievances: what has worked until today in preventing an open contestation in Uruguay, such as a strong state support and a conflict culture that eschews from conflict, are likely to work also in the future. Forestry corporations may still enjoy a supposed SLO in Uruguay for many years; bringing to light the real state of affairs and the absence of local support in several locations will be feasible only once the political barriers to effectively raise local voices are overcome.

The discrepancies between global certification standards and local grievances were apparent in our cases. The standards that serve as the basis for evaluating behaviour of the company towards the local community, in particular the FSC's third principle on Indigenous rights and the fourth principle on enhancing the community's social and economic well-being, do not cover all aspects of local discontent towards the company being assessed for certification. Where national laws clash with Indigenous claims for 
territory, FSC evaluation departs from the local regulatory framework, leaving the Indigenous claims unattended (this took place in the Chilean case studied in this article, and it has also taken place in Eastern Brazil, see e.g. Kröger, 2013a and M yllylä and Takala, 2011). If certification schemes are to stand a chance to guarantee locally grounded social sustainability in the long-term, there is a need to incorporate principles that give local populations the right to reject (the right of veto ${ }^{5}$ ) certification in case their livelihoods or ways of life are threatened.

Perhaps most importantly, we found that SLO also carries with it a major ethical dilemma and burden when entering into the realm of ontologically different worldviews. The references made by interviewees in Chile to 'selling oneself' indicate that local acceptability cannot be bought through compensation packages or investments of some of the created 'shared value' in local development programmes. The attitudes towards industrial operations are not defined by mere self-driven interests, but also depend on the identity and worldviews of the community members and the community as a whole. How they see themselves and the world in which they live greatly influences their disposition to engage with companies, whose core operations threaten their identity and subsistence. When an investment model is imposed across an ontological cleavage that is not recognised, and is used as a tool to engulf particular place-based Indigenous or other non-modern cosmologies under the conceptual world of capitalism, it is inherently impossible (and unethical) to produce an outcome that enjoys the acceptance of the locals.

Our material suggests that SLO is what the state supports and not necessarily what locals support. To talk about local acceptance without giving the locals a voice of their own is an act of violence that silences dissent and only makes it harder for locals to unify and take actions based on their own (potential and nascent) belief systems. A more balanced debate on corporate-community relations must open up for a broader perspective on what it means to have access to a living environment that provides all community members the opportunities to sustain their lives, in the place that they inhabit.

It is not the large investments and the connection to global markets per se that provide remote rural villages with the solutions on how to live and sustain their lives in community. The use of SLO as an indicator of local acceptance makes it difficult to envision all those alternative ways of life that do not demand the presence global corporations. Instead, focusing on the different modes of production that maximizes the locals' capacity to reproduce and sustain life in their community based on their own desires and needs, opens up the collective capacity to imagine other possible ways of living. Conflicts emerge in those places when locals are aware of how particular investments do not support their capacity to sustain life but instead pose tangible threats of destroying (all) life in community.

To conclude, we would like to ask: who benefits from SLO with limited local support? From an ethical and socio-environmental perspective, the recognition of conflicting interests and the absence of SLO may be better options if an investment is causing damage at the local level. The primary focus of investors and regulators should be to ensure a sound investment policy that does not occlude local realities and incommensurable differences on the ground.

\section{References}

1.

- $\quad$ Acosta, 2013

- A. Acosta

- Extractivism and neoextractivism: two sides of the same curse 
- M. Lang (Ed.), Beyond Development Alternative Visions from Latin America, Rosa Luxemburg Foundation, Quito (2013)

○

2.

- $\quad$ Adams, 2011

- J. Adams

- Submission No. 35: Inquiry into the Australian Forestry Industry. Submitted by Timber Communities Australia (TCA) to the Australian Government's House of Representatives Standing Committee on Agriculture, Resources, Fisheries and Forestry

○ (2011)

O

3.

- Banerjee, 2011

- S.B. Banerjee

- Voices of the governed: towards a theory of the 'translocal'

- Organization, 18 (2011), pp. 323-344

- $\underline{\text { CrossRef }}$

|

View Record in Scopus

Loading

4.

- Barton et al., 2012

- J. Barton, A. Román, A. Floysand

- Resource extraction and local justice in Chile: conflicts over the commodification of spaces and the sustainable development of places

- H. Haarstad (Ed.), New Political Spaces in Latin American Natural Resource Governance, Palgrave, New York (2012), pp. 107-128

- CrossRef

|

View Record in Scopus

Loading

5.

- Bice and M offat, 2014 
- S. Bice, K. M offat

- Social licence to operate and impact assessment

- Impact Assess. Proj. Appriasal, 32 (2014), pp. 257-262

- CrossRef

|

View Record in Scopus

Loading

6.

- Blaser, 2010

- M. Blaser

- Storytelling Globalization from the Chaco and Beyond

- Duke University Press, Durham and London (2010)

$\circ$

7.

- Boutilier, 2014

- R. Boutilier

- Frequently asked questions about the social licence to operate

- Impact Assess. Proj. Appraisal, 32 (2014), pp. 263-272

- $\underline{\text { CrossRef }}$

$\underline{\text { View Record in Scopus }}$

Loading

8.

- Boutilier and Thomson, 2012

- Boutilier, R. and Thomson, I. 2012 From Metaphor to Management Tool - How the Social Licence to Operate can Stabilise the Socio-Political Environment for Business. Conference Paper presented at International M ine M anagement Conference 2012. Available at: http://www.accsr.com.au/pdf/Boutilier_Black_Thomson_From_M etaphor_To_Mgmt_T ool FINAL_AUSIM M PROCEEDINGS_20120802.pdf.

O

9.

- Carruthers and Rodriguez, 2009 
- D. Carruthers, P. Rodriguez

- Mapuche protest, environmental conflict and social movement linkage in Chile

- Third World Q., 30 (2009), pp. 743-760

- CrossRef

|

View Record in Scopus

Loading

10.

- Cashore, 2004

- B. Cashore

- Legitimacy and the privatization of environmental governance: how non-state marketdriven (NSMD) governance systems gain rule-making authority

- Governance, 15 (2004), pp. 503-529

- View Record in Scopus

Loading

11.

- Clapp, 1995

○ R. Clapp

- Creating competitive advantage: forest policy as industrial policy in Chile

- Econ. Geogr., 71 (1995), pp. 273-296

- $\underline{\text { CrossRef }}$

।

View Record in Scopus

Loading

12.

- Cayuqueo, 2012

- P. Cayuqueo

- Solo por ser indios y otras crónicas mapuches

- Catalonia, Santiago (2012)

13. 
- Collier, 2010

- P. Collier

- The political economy of natural resources

○ Soc. Res., 77 (2010), pp. 1105-1132

- View Record in Scopus

Loading

14.

- Comunidad de Historia Mapuche, 2012

- Comunidad de Historia M apuche

- Ta Iñ Fijke Xipa Rakizuameluwün - Historia, colonialismo y resistencia desde el país Mapuche

- Ediciones Comunidad de Historia Mapuche, Temuco (2012) 377 pp.

$\circ$

15.

- Costanza, 2015

- J. Costanza

$\circ$ Indigenous peoples' right to prior consultation: transforming human rights from the grassroots in Guatemala

$\circ \quad$ J. Hum. Rights, 14 (2015), pp. 260-285

- $\underline{\text { CrossRef }}$

|

View Record in Scopus

Loading

16.

- Dare et al., 2014

- M. Dare, J. Schirmer, F. Vanclay

- Community engagement and social licence to opérate

- Impact Assess. Proj. Apprais., 32 (2014), pp. 188-197

- CrossRef

$$
\text { I }
$$

View Record in Scopus 
17.

- Dauvergne and Lister, 2011

- P. Dauvergne, J. Lister

- Timber

- Polity Press, Cambridge (2011)

$\circ$

18.

- Delamaza, 2012

- G. Delamaza

- Responsabilidad social empresarial, política e internacionalización. El caso del "conflicto de los cisnes" en Valdivia, Chile

- Apuntes, 70 (2012), pp. 167-201

$\circ$

19.

- Ehrnström-Fuentes, 2015

- M. Ehrnström-Fuentes

- Production of absence through media representation: a case study on legitimacy and deliberation of a pulp mill dispute in southern Chile

- Geoforum, 59 (2015), pp. 51-62

- Article

|

PDF (382 K)

।

View Record in Scopus

Loading

20.

- Ehrnström-Fuentes, 2016

- M. Ehrnström-Fuentes

- Delinking legitimacies - a pluriversal perspective on political CSR

○ J. Manag. Stud., 53 (2016), pp. 433-462

- $\underline{\text { CrossRef }}$ 
View Record in Scopus

Loading

1.

- Ehrnström-Fuentes, 2012

- Ehrnström-Fuentes, M. 2012 "It's over Barbie" - Risk Identification in Pulp Procurement. Conference Paper presented at the 11th International Conference on Corporate Social Responsibility, May 8-10, 2012, Lahti, Finland.

○

2.

- Edwards and Lacey, 2014

- P. Edwards, J. Lacey

- Can't climb the trees anymore: social licence to operate, bioenergy and whole stump removal in Sweden

- Soc. Epistemol., 28 (2014), pp. 239-257

- CrossRef

।

View Record in Scopus

Loading

3.

- Escobar, 2008

- A. Escobar

- Territories of Difference: Place, M ovements, Life, Redes

- Duke University Press, Durham and London (2008)

○

4.

- Escobar, 2011

- A. Escobar

- Encountering Development: The Making and Unmaking of the Third World

- (second ed.)Princeton University Press, Princeton (2011)

○

5.

- Esteves and Vanclay, 2009 
- A.M. Esteves, F. Vanclay

- Social development needs analysis as a tool for SIA to guide corporate-community investment: applications in the minerals industry

- Environ. Impact Assess. Rev., 29 (2009), pp. 137-

145 http:// dx.doi.org/10.1016/j.eiar.2008.08.004

- Article

|

$\underline{\operatorname{PDF}(474 \mathrm{~K})}$

|

$\underline{\text { View Record in Scopus }}$

Loading

6.

- Fernández and Henríquez, 2009

- P. Fernández, A. Henríquez

- La voz mapuche

- (2009) [Documentary]. Chile and Argentina. Available

at http://www.cultureunplugged.com/play/6068/The-Voice-of-the-M apuche

7.

- $\underline{\text { FSC, } 2015}$

- FSC

- FSC Principles and Criteria for Forestry Stewardship

- Forestry Stewardship Council, Bonn (2015) Available

at https://ic.fsc.org/en/certification/principles-and-criteria

$\bigcirc$

8.

- $\underline{\text { FSC, } 2012}$

- FSC

- FSC Guidelines for the Implementations of the Right to Free, Prior and Informed Consent (FPIC). Version 1. 30 October 2012

- Forestry Stewardship Council, Bonn (2012)

○

9. 
- Fougère and Solitander, 2009

- M. Fougère, N. Solitander

- Against corporate responsibility: critical reflections on thinking, practice, content and consequences

- Corp. Soc. Responsib. Environ. Mgmt., 16 (2009), pp. 217-227

- $\underline{\text { CrossRef }}$

|

View Record in Scopus

Loading

10.

- Gallagher and Porzecanski, 2010

- K. Gallagher, R. Porzecanski

- The Dragon in the Room China and the Future of Latin American Industrialization

- Stanford University Press, Stanford (2010)

○

11.

- Gerber, 2011

- J.-F. Gerber

- Conflicts over industrial tree plantations in the - south: who, how and why?

- Glob. Environ. Change, 21 (2011), pp. 165-176

- $\underline{\text { Article }}$

|

PDF (216 K)

|

View Record in Scopus

Loading

12.

- Gómez-Barris, 2012

- M. Gómez-Barris

- Mapuche hunger acts: epistemology of the decolonial

- Transmodernity, 1 (2012) 
13.

- Groglopo, 2012

- A. Groglopo

- Appropriation by Coloniality - TNCs, Land, Hegemony and Resistance: The Case of Botnia/ UPM in Uruguay. Doctoral Thesis

- Umeå University, Department of Sociology (2012)

$\circ$

14.

- Gudynas, 2011

- E. Gudynas

○ Buen Vivir: today's tomorrow

- Development, 54 (2011), pp. 441-447

- $\underline{\text { CrossRef }}$

।

View Record in Scopus

Loading

15.

- Gudynas, 2012

- E. Gudynas

- Estado compensador e nuevos extractivismos: las ambivalencias del progresismo sudamericano

- Nueva Soc., 237 (2012), pp. 128-146

- View Record in Scopus

Loading

16.

- Gunningham et al., 2004

- N. Gunningham, R. Kagan, D. Thornton

- Social license and environmental protection: why businesses go beyond compliance

- Law Soc. Inq., 29 (2004), pp. 307-340

0

17. 
- $\quad$ Hall et al., 2012

- N. Hall, J. Lacey, S. Carr-Cornish, A.-M. Dowd

- Social licence to operate: understanding how a concept has been translated into practice in energy industries

○ J. Clean. Prod., 86 (2012), pp. 301-310

O

18.

- Hanna and Vanclay, 2013

- P. Hanna, F. Vanclay

- Human rights, indigenous peoples and the concept of free, prior, and informed consent

- Impact Assess. Proj. Apprais., 31 (2013), pp. 149-157

O

19.

- Hanna et al., 2014

- P. Hanna, F. Vanclay, E.J. Langdon, J. Arts

- Improving the effectiveness of impact assessment pertaining to indigenous peoples in the Brazilian environmental licensing procedure

- Environ. Impact Assess. Rev., 46 (2014), pp. 58-67

- Article

|

$\underline{\operatorname{PDF}(736 \mathrm{~K})}$

|

View Record in Scopus

Loading

20.

- Haughney, 2012

○ D. Haughney

- Defending territory, demanding participation: Mapuche struggles in Chile

- Lat. Am. Perspect., 39 (2012), pp. 201-217

- CrossRef

View Record in Scopus 
1.

- Harvey, 2013

- B. Harvey

- Social development will not deliver social license to operate for the extractive sector

- Extr. Industries Soc., 1 (2013), pp. 7-11

$\circ$

2.

- Harvey and Bice, 2014

- B. Harvey, S. Bice

- Social impact assessment, social development programmes and social licence to operate: tensions and contradictions in intent and practice in the extractive sector

- Impact Assess. Proj. Apprais., 32 (2014), pp. 327-335

- $\underline{\text { CrossRef }}$

।

View Record in Scopus

Loading

3.

- Hilson, 2012

○ G. Hilson

- Corporate social responsibility in the extractive industries: experiences from developing countries

- Resour. Policy, 37 (2012), pp. 131-137

- Article

I

$\underline{\operatorname{PDF}(152 \mathrm{~K})}$

|

View Record in Scopus

Loading

4.

- Human Rights Watch, 2004

- Human Rights Watch 
- Undue Process - Terrorism Trials, Military Courts and the Mapuche in Southem Chile, New York, October, 27, 2004

- (2004) http://www.hrw.org/node/11920/section/2

○

5.

- $\lfloor$ ackson, 2015

- S. Jackson

- Dusty roads and disconnections: perceptions of dust from unpaved mining roads in Mongolia's South Gobi province

○ Geoforum, 66 (2015), pp. 94-105

- Article

PDF (2595 K)

|

View Record in Scopus

Loading

6.

- Lijelava and Vanclay, 2014

- Jijelava, Vanclay

- Social licence to operate through a gender lens: the challenges of including women's interests in development assistance projects

- Impact Assess. Proj. Apprais., 32 (2014), pp. 283-

293http://dx.doi.org/10.1080/14615517.2014.933505

- $\underline{\text { CrossRef }}$

$\underline{\text { View Record in Scopus }}$

Loading

7.

- Lohansson, 2014a

- J. Johansson

- Towards democratic and effective forest governance? The discursive legitimation of forest certification in northern Sweden

○ Local Environ. Int. J. Justice Sustain., 19 (2014), pp. 803-819 


\section{- CrossRef}

|

View Record in Scopus

Loading

8.

- Lohansson, 2014b

- J. Johansson

- Why do forest companies change their CSR strategies? Responses to market demands and public regulation through dual-certification

○ J. Environ. Plan. M anag., 57 (2014), pp. 349-368

- $\underline{\text { CrossRef }}$

View Record in Scopus

Loading

9.

- Loutsenvirta, 2011

- M. Joutsenvirta

- Setting boundaries for corporate social responsibility: firm- NGO relationship as discursive legitimation struggle

○ J. Bus. Ethics, 102 (2011), pp. 57-75

- $\underline{\text { CrossRef }}$

$\underline{\text { View Record in Scopus }}$

Loading

10.

- Kowalczyk, 2013

- A.M. Kowalczyk

- Indigenous peoples and modernity: Mapuche mobilizations in Chile

- Lat. Am. Perspect., 40 (2013), pp. 121-135

- CrossRef

View Record in Scopus 
11.

- Kröger, 2015

- M. Kröger

- Spatial causalities in resource rushes: notes from the finnish mining boom

○ J. Agrar. Change (2015) http://dx.doi.org/10.1111/joac.12113

$\circ$

12.

- Kröger, 2014

- M. Kröger

- The political economy of global tree plantation expansion: a review

- J. Peasant Stud., 41 (2014), pp. 235-261

- $\underline{\text { CrossRef }}$

|

View Record in Scopus

Loading

13.

- Kröger, 2013a

- M. Kröger

- Contentious Agency and Natural Resource Politics

- Routledge, London (2013) 174pp

$\circ$

14.

- Kröger, 2013b

- M. Kröger

- Grievances, agency and the absence of conflict: the new Suzano pulp investment in the Eastern Amazon

- For. Policy Econ., 33 (2013), pp. 28-35

- Article

$\underline{\operatorname{PDF}(187 \mathrm{~K})}$ 
$\underline{\text { View Record in Scopus }}$

\section{Loading}

15.

- Kröger, 2013c

- M. Kröger

- Globalization as the "pulping" of landscapes: forestry Capitalism's North- south territorial accumulation

- Globalizations, 10 (2013), pp. 837-853

- $\underline{\text { CrossRef }}$

|

$\underline{\text { View Record in Scopus }}$

Loading

16.

- Kröger, 2012a

- M. Kröger

- The expansion of industrial tree plantations and dispossession in Brazil

○ Dev. Change, 43 (2012), pp. 947-973

- $\underline{\text { CrossRef }}$

|

View Record in Scopus

Loading

17.

- Kröger, 2012b

- M. Kröger

- Neo-mercantilist capitalism and post-2008 cleavages in economic decisionmaking power in Brazil

○ Third World Q., 33 (2012), pp. 887-901

- CrossRef

$$
\text { । }
$$

View Record in Scopus 
18.

- Kröger Kröger, 2011

- M. Kröger

- Promotion of contentious agency as a rewarding movement strategy: evidence from the MST-paper industry conflicts in Brazil

- J. Peasant Stud., 38 (2011), pp. 435-458

- $\underline{\text { CrossRef }}$

View Record in Scopus

\section{Loading}

19.

- Kröger and Nylund, 2011

- M. Kröger, J.-E. Nylund

- The conflict over Veracel pulpwood plantations in Brazil: application of ethical analysis

- For. Policy Econ., 14 (2011), pp. 74-82

○

20.

- Kröger, 2010

- M. Kröger

- The Politics of Pulp Investment and the Brazilian Landless Movement (M ST). Acta Politica 39

- University of Helsinki (2010)

O

1.

- Kröger, 2007

- M. Kröger

- Uruguayn ja Argentiinan sellutehdaskonflikti latinalaisamerikkalaisena maa- ja metsäkilistana. Kosmopolis 37, 23-42. [' The Uruguayan and Argentinean Pulp Mill Conflict as a Latin American Land and Forest Dispute']

○ (2007)

o

2. 
- M arimán et al., 2006

- P. Marimán, S. Caniuqueo, J. Millalén, R. Levil

○ Escucha Winka

- LOM Ediciones, Santiago (2006)

$\circ$

3.

- M cDermott, 2012

- C. M cDermott

- Trust, legitimacy and power in forest certification: a case study of the FSC in British Columbia

- Geoforum, 43 (2012), pp. 634-644

- $\underline{\text { Article }}$

$\underline{\operatorname{PDF}(227 \mathrm{~K})}$

|

View Record in Scopus

Loading

4.

- M artinez and Franks, 2014

- C. M artinez, D. Franks

- Does mining company-sponsored community development influence sociallicence to operate? Evidence from private and state owned companies in Chile

- Impact Assess. Proj. Apprais., 32 (2014), pp. 294-303

- $\underline{\text { CrossRef }}$

I

View Record in Scopus

Loading

5.

- M elé and Armengou, 2015

- D. M elé, J. Armengou

- Moral legitimacy in controversial projects and its relationship with Social License to Operate: A Case Study 
○ J. Bus. Ethics, 136 (2016), pp. 729-742

- $\underline{\text { CrossRef }}$

|

View Record in Scopus

Loading

6.

- Mena and Palazzo, 2012

- S. Mena, G. Palazzo

- Input and output legitimacy of multistakeholder initiatives

- Bus. Ethics Q., 22 (2012), pp. 527-556

- $\underline{\text { CrossRef }}$

|

View Record in Scopus

Loading

7.

○ $\quad$ Mitchell et al., 1997

- R. Mitchell, B. Agle, D. Wood

- Toward a theory of stakeholder identification and salience: defining the principle of who and what really

- Acad. Manag. Rev., 22 (1997), pp. 853-886

- $\underline{\text { CrossRef }}$

।

$\underline{\text { View Record in Scopus }}$

Loading

8.

- Moffat and Zhang, 2014

- K. M offat, A. Zhang

- The paths to social licence to operate: an integrative model explaining community acceptance of mining

○ Resour. Policy, 39 (2014), pp. 61-70

- Article 
$\underline{\operatorname{PDF}(457 \mathrm{~K})}$

|

View Record in Scopus

Loading

9.

- Moog et al., 2014

- S. Moog, A. Spicer, S. Böhm

- The politics of multi-stakeholder initiatives: the crisis of the forest stewardship council

○ J. Bus. Ethics, 128 (2015), pp. 469-493

- $\underline{\text { CrossRef }}$

View Record in Scopus

Loading

10.

- Moore, 2014

- J. Moore

- The Capitalocene II

- (2014) http://www.jasonwmoore.com/uploads/The Capitalocene Part II June 2014.p df

○

11.

- M yllylä and Takala, 2011

○ S. Myllylä, T. Takala

- Leaking legitimacies: the Finnish forest sector's entanglement in the land conflicts of Atlantic coastal Brazil

- Soc. Responsib. J., 7 (2011), pp. 42-60

$\circ$ CrossRef

|

View Record in Scopus

Loading

12.

- Nylund and Kröger, 2012 
○ J.-E. Nylund, M. Kröger

- Cleavage in the understanding of sustainability: sustainable pulp industry versus sustained local livelihood

- Scand. J. For. Res., 27 (2012), pp. 229-240

- CrossRef

|

View Record in Scopus

Loading

13.

- Owen and Kemp, 2012

- J.R. Owen, D. Kemp

- Social licence and mining: a critical perspective

- Resour. Policy, 38 (2012), pp. 29-35

- View Record in Scopus

Loading

14.

- Palazzo and Scherer, 2006

- G. Palazzo, A. Scherer

- Corporate legitimacy as deliberation. A communicative framework

○ J. Bus. Ethics, 66 (2006), pp. 71-88

- $\underline{\text { CrossRef }}$

|

View Record in Scopus

Loading

15.

- Pakkasvirta, 2010

- J. Pakkasvirta

- Fábricas de celulosa: historias de la globalizacion

- La Colmena, Buenos Aires (2010)

$\circ$

16. 
- Parsons et al., 2014

- R. Parsons, J. Lacey, K. M offat

- M aintaining legitimacy of a contested practice: how the minerals industry understands its 'social licence to operate'

- Resour. Policy, 41 (2014), pp. 83-90

- Article

|

$\underline{\operatorname{PDF}(303 \mathrm{~K})}$

|

View Record in Scopus

Loading

17.

- Parsons and M offat, 2014

- K. Parsons, K. M offat

- Constructing the meaning of social licence

- Soc. Epistemol., 28 (2014), pp. 340-363

○

18.

- Piñeiro, 2012

- D. Piñeiro

- Land grabbing: concentration and "foreignisation" of land in Uruguay

- Can. J. Dev. Stud., 33 (2012), pp. 471-489

- CrossRef

View Record in Scopus

Loading

19.

- $\quad$ Porter and Kramer, 2011

- M. Porter, M. Kramer

- Creating shared value

- Harv. Bus. Rev., 89 (2011), pp. 62-77 


\section{- View Record in Scopus}

Loading

20.

- Prno, 2013

○ J. Prno

- An analysis of factors leading to the establishment of a social licence to operate in the mining industry

- Resour. Policy, 37 (2013), pp. 577-590

- $\underline{\text { Article }}$

।

$\underline{\operatorname{PDF}(761 \mathrm{~K})}$

|

View Record in Scopus

Loading

1.

- Prno and Slocombe, 2012

- J. Prno, S. Slocombe

- Exploring the origins of 'social license to operate' in the mining sector: perspectives from governance and sustainability theories

- Resour. Policy, 37 (2012), pp. 346-357

- Article

\section{$\underline{\operatorname{PDF}(376 \mathrm{~K})}$}

|

View Record in Scopus

Loading

2.

- Roberge et al., 2011

- A. Roberge, L. Bouthillier, J. Mercier

- The gap between theory and reality of governance: the case of forest certification in Quebec (Canada)

- Soc. Nat. Resour., 24 (2011), pp. 656-671 


\section{- CrossRef}

|

View Record in Scopus

Loading

3.

- Ruckstuhl et al., 2014

- K. Ruckstuhl, M. Thompson-Fawcett, H. Rae

- Maori and mining: indigenous perspectives on reconceptualising and contextualising the social licence to operate

- Impact Assess. Proj. Appraisal, 32 (2014), pp. 304-314

- $\underline{\text { CrossRef }}$

View Record in Scopus

Loading

4.

- Schepers, 2010

- D. Schepers

- Challenges to legitimacy at the forest stewardship council

○ J. Bus. Ethics, 92 (2010), pp. 279-290

- CrossRef

View Record in Scopus

Loading

5.

- Scherer and Palazzo, 2007

- A. Scherer, G. Palazzo

- Toward a political conception of corporate responsibility: business and society seen from a habermasian perspective

- Acad. Manag. Rev., 32 (2007), pp. 1096-1120

- CrossRef

View Record in Scopus 
6.

- Sepúlveda and Villarroel, 2012

- C. Sepúlveda, P. Villarroel

- Swans, conflicts and resonance: local movements and the reform of chilean environmental institutions

- Lat. Am. Perspect., 39 (2012), pp. 181-200

- $\underline{\text { CrossRef }}$

|

View Record in Scopus

Loading

7.

- Silva, 2009

- E. Silva

- Challenging Neoliberalism in Latin America

- Cambridge University Press, New York (2009)

○

8.

- $\underline{\text { Sing, } 2015}$

$\circ$ J. Sing

- Regulating mining resource investments towards sustainable development: the case of Papua New Guinea

- Extr. Ind. Soc., 2 (2015), pp. 124-131

- $\underline{\text { Article }}$

|

$\underline{\operatorname{PDF}(391 \mathrm{~K})}$

|

View Record in Scopus

Loading

9.

- Soule, 2009

- S. Soule 
- Contention and Corporate Social Responsibility

- Cambridge University Press, Cambridge (2009)

O

10.

- Stora Enso, 2015

- Stora Enso

- Progress Book. Part of Stora Enso's Annual Report 2014

- (2015) Available

at http://assets.storaenso.com/se/com/DownloadCenterDocuments/Reports SE Global R esponsibility_Report_2011 english.pdf (accessed on 20.10.15)

$\circ$

11.

- The Danish Institute for Human Rights, 2015

- The Danish Institute for Human Rights

- Stora Enso Human Rights Assessment Review and Consolidation Report. Copenhagen

- (2015) 40 pp. Available at http://assets.storaenso.com/se/com/DownloadCenterDocuments/0502HRA_2015 DIHR REPORT.pdf (accessed 20.10.15)

○

12.

- $\underline{\text { Tingle, } 2015}$

$\circ \quad$ L. Tingle

- Political amnesia: how we forgot how to govem

- Q. Essay, 60 (2015), pp. 1-86

- View Record in Scopus

Loading

13.

$\circ \underline{\text { UPM }, 2015}$

○ UPM

- Forest-based Industries Have a Significant Role in Promoting Sustainable Development

- (2015) (accessed on 20 Octobre, 2015) http:// www.upm.com/Responsibility/forests/principles/Pages/default.aspx 
14.

- Varela, 2011

- E. Varela

- Newen Mapuche

- (2011) [Documentary]. Chile: Ojofilm Productora. Available at http://www.chiledoc.cl/?p=432 (accessed on 20.06.15)

0

15.
- Wang, 2005
- S. Wang
- Managing Canada's forests under a new social contract
○ For. Chron., 81 (2005), pp. 486-490
- $\underline{\text { CrossRef }}$

View Record in Scopus

Loading

16.

- Westoby and Lyons, 2016

- P. Westoby, K. Lyons

- Privatising development and environmental management: undermining social license in the Ugandan plantation forest sector

○ Environ. Sociol. (2016) http:// dx.doi.org/10.1080/23251042.2016.1163963

$\circ$

17.

- Wilburn and Wilburn, 2011

○ K.M. Wilburn, R. Wilburn

- Achieving social license to operate using stakeholder theory

○ J. Int. Bus. Ethics, 4 (2011), pp. 3-16

- View Record in Scopus

Loading

18.

- Zhang et al., 2015 
- A. Zhang, K. M offat, J. Lacey, J. Wang, R. González, K. Uribe, L. Cui, Y. Dai

- Understanding the social licence to operate of mining at the national scale: a comparative study of Australia, China and Chile

○ J. Clean. Prod., 108 (2015), pp. 1063-1072

By the term ITP, we refer to 'non-edible tree species cultivated in ... industrial large-scale forestry plantations of hundreds of hectares contractually controlled or owned by corporations'; the term TP includes also the other social actors that control tree plantations (corporate, smallholder, public and community) (Kröger, 2014, p. 238). This conceptualization focuses on power and who controls the plantations, and can be seen thus more apt to be used in the study of SLO than conceptualizations that do not deal with tenure or control but focus on the production style for example.

$\underline{2}$

The shift towards private politics has had worrying impacts in general, according to Tingle (2015) for example. She argues that the wider trend to diminish the critical capacities of regulatory agencies by outsourcing assessment to 'consultants' is problematic, as they are structurally inhibited from offering fearless advice to decision-makers.

\section{$\underline{3}$}

Also the FSC has adapted guidelines on the right to free prior informed consent by local and indigenous groups before the projects starts (ㅌㄷ, 2012).

\section{$\underline{4}$}

In a recent study on mining in M ongolia, Lackson (2015) shows how dust can become political through its power to transform place, creating distances and disconnections between people, livelihoods, and landscapes.

\section{$\underline{5}$}

Whether the 'consent' within the free, prior, and informed consent guidlelines actually signifies that locals should have a veto power is currently a widely debated topic (Costanza, 2015); the FSC guidelines state that this principle does not give locals the right to veto, instead it is designed to 'empower community to protect their rights' within the realm of 'fair and reasonable demands' (ESC, 2012, p. 11). 